Acta vet. scand. 1976, 17, 131-141.

From the State Veterinary Institute for Virus Research, Lindholm, Kalvehave, Denmark.

\title{
SEROLOGICAL DIAGNOSIS OF CLASSICAL SWINE FEVER
}

\author{
A COMPARISON OF A MODIFIED DIRECT COMPLEMENT \\ FIXATION TEST WITH AN IMMUNOFLUORESCENCE \\ PLAQUE NEUTRALIZATION TEST IN THE DIAGNOSIS OF \\ EXPERIMENTAL SUBCLINICAL INFECTION*
}

By

M. Eskildsen and E. Overby

\begin{abstract}
ESKILDSEN, M. and E. OVERBY: Serological diagnosis of classical swine fever. A comparison of a modified direct complement fixation test with an immunofluorescence plaque neutralization test in the diagnosis of experimental subclinical infection. Acta vet. scand. 1976, 17, 131-141. - Antibody levels in post-infection sera from a pig inoculated with a low virulent strain of classical swine fever virus (Hannover 62) and in sera from two pigs inoculated with another low virulent strain (Spielbach 66) and from an in-contact pig were assayed by complement fixation and immunofluorescence using classical swine fever virus (ALD strain) and bovine virus diarrhoea virus (UG 59 strain) as antigens. The complement fixation test used was modified by addition of a preparation of porcine $\mathrm{C1q}$ to the complement and by mercaptoethanol treatment of the immune serum before use. The mercaptoethanol treatment of the immune serum resulted in complete elimination of a haemolytic prozone often seen with porcine immune sera.

In the sera from the inoculated animals complement-fixing antibodies appeared earlier than neutralizing antibodies. A few weeks after inoculation there was a correlation between the presence of complement-fixing and neutralizing antibodies.

During the entire observation period of 13 weeks it was not possible to demonstrate complement-fixing or neutralizing antibodies in serum from a pig exposed to infection by contact with the two pigs inoculated with the Spielbach 66 strain of classical swine fever virus.
\end{abstract}

classical swine fever; complement fixation; immunofluorescense plaque neutralization.

* This work was in part supported by a grant from the European Economic Community's Agricultural Committee. 
In the diagnosis of classical swine fever (CSF) the antigen can be demonstrated by immunofluorescence and complement fixation (Mengeling et al. $1963 \mathrm{a}, \mathrm{b}$, Boulanger et al. 1965, Mengeling 1968, Meyling \& Schjerning-Thiesen 1968, Korn et al. 1969). In the demonstration of specific antibodies in swine serum direct complement fixation (Gutekunst \& Malmquist 1964, Jakubik 1969) has not been commonly used owing to inherent properties of swine serum interfering with complement fixation. Using hyperimmune swine sera Gutekunst \& Malmquist found the complement fixation test useful when the direct test was modified by addition of unheated calf serum to the complement diluent to enhance fixation and by pretreatment of the swine serum with formalin (Cowan 1961) to remove the procomplementary activity.

The complement fixation test used in the present work was modified by addition of a preparation of porcine C1q to the complement diluent instead of calf serum and by pretreatment of the swine immune serum with mercaptoethanol (Eskildsen $1975 \mathrm{~b})$ to eliminate a haemolytic prozone often seen with porcine sera. CSF virus and bovine virus diarrhoea (BVD) virus were used as antigens. The modified test was applied in the demonstration of antibodies in post-infection sera from pigs inoculated once experimentally with low virulent strains of CSF virus. The results obtained by complement fixation were compared with those obtained by an immunofluorescence plaque neutralization test (Carbry et al. 1969, Overby 1973).

\section{MATERIALS AND METHODS}

\section{Inoculation of animals}

The pigs used were of the Danish Landrace, weighing about $25 \mathrm{~kg}$. In one experiment two pigs were inoculated intravenously with the Hannover 62 strain of CSF virus. A third pig passage was used, and $2 \mathrm{ml}$ of virus-containing blood was used as inoculum. In another experiment two pigs were inoculated with the Spielbach 66 virus strain and one pig served as control and in-contact animal. Spleen material from inoculated pigs was used as inoculum, and $2 \mathrm{ml}$ of a $10 \%$ suspension was given intravenously. Blood samples were collected at weekly intervals after inoculation. 
Virus for tissue culture inoculation

The Japanese ALD strain of CSF virus (40th cell culture passage) was used for inoculation of primary pig kidney cell cultures. The UG 59 strain of BVD virus was used after 12 passages for inoculation of primary calf kidney and secondary calf testicle cell cultures. This strain is cytopathogenic and was isolated during an outbreak of mucosal disease in a Danish cattle herd (Borgen 1963). It has been found to have immunizing effect against swine fever (Overby 1973).

\section{Immunofluorescence plaque neutralization test}

Monolayers of primary pig kidney cell cultures were cultivated in $10 \times 50 \mathrm{~mm}$ coverslips in Leighton tubes. As growth medium was used a modified Hanks' vitaminized balanced salt solution with addition of $0.75 \mathrm{~g} \mathrm{NaHCO}_{3}$ per $1,0.5 \%$ lactalbumin hydrolysate, $0.1 \%$ glucose and $10 \%$ calf serum. The coverslips, seeded with a suspension containing $50-100 \times 10^{3}$ cells per ml, were covered with a confluent sheet in $4-5$ days. The maintenance medium was Earle's balanced salt solution supplemented with vitamins, lactalbumin hydrolysate and antibiotics.

The titre of antibodies in the serum samples was determined by making twofold dilutions of serum and mixing with equal amounts of virus suspension containing 500-1000 TCID50/0.1 $\mathrm{ml}$. The mixtures were placed at $37^{\circ} \mathrm{C}$ for $60 \mathrm{~min}$. and then inoculated into primary cell cultures in Leighton tubes. Each mixture was inoculated into three tubes, $0.2 \mathrm{ml}$ per tube. A few control cultures were inoculated with virus suspension only. After incubation at $37^{\circ} \mathrm{C}$ for two days the coverslips were removed for staining and microscopy. The titre of serum was expressed as the highest dilution causing a $50 \%$ reduction in the number of primary foci within 10 different sight fields distributed all over the culture sheet.

\section{Complement fixation}

a. Antigen. Primary pig kidney cells for the ALD virus strain and secondary calf testicle cells for the UG 59 virus strain were grown in roller bottles with the modified Hanks' balanced salt solution containing $10 \%$ calf serum. Maintenance medium was Earle's balanced salt solution supplemented with lactalbumin 
hydrolysate and vitamins. After inoculation the roller bottles were incubated at $37^{\circ} \mathrm{C}$ until the intracellular virus content had reached maximum as judged by immunofluorescence in Leighton tubes inoculated simultaneously. Then the cells were removed from the bottles by scraping, pelleted by low speed centrifugation and resuspended in PBS, $\mathrm{pH} 7.2$, to $1 / 10$ of the original volume of medium. After that the cell suspension was exposed to sonic oscillation at $20 \mathrm{kc} / \mathrm{sec}$. for $2 \mathrm{~min}$. After high speed centrifugation $\left(10,000 \times \mathrm{g} / 10 \mathrm{~min} . / 0^{\circ} \mathrm{C}\right)$ the clear supernatant was distributed in small volumes and these kept at $-60^{\circ} \mathrm{C}$. With both types of cell culture a corresponding control antigen was prepared from noninoculated cell cultures. Only cell cultures of satisfactory quality were used. The antigens were tested by block titrations. If they were anticomplementary they were not used.

b. Sera. Before titration in complement fixation the sera were treated with mercaptoethanol as described earlier (Eskildsen $1975 \mathrm{~b}$ ). A $0.06 \mathrm{M}$ solution of mercaptoethanol in a $0.05 \mathrm{M}$ Tris buffer $\mathrm{pH} 7.0$, containing $0.56 \% \mathrm{NaCl}$ was used. Equal volumes of serum and mercaptoethanol solution were mixed and incubated at $56^{\circ} \mathrm{C}$ for $20 \mathrm{~min}$. During this incubation a precipitate was formed. After freezing in alcohol at $-20^{\circ} \mathrm{C}$ and thawing this precipitate could easily be removed by low speed centrifugation. The clear supernatant was used in the complement fixation test. If the precipitate was not removed, an anticomplementary activity was seen with some sera.

c. Technique. Diluent, complement and haemolytic system were used as described by Schjerning-Thiesen (1964). Direct complement fixation with microtiter equipment (Cooke Engineering) was applied. Two $100 \%$ haemolytic units of complement were used. A preparation of porcine C1q was added to the complement diluent in appropriate concentration, usually $4 \%$ (v/v). The C1q preparation was made by dialysis of normal swine serum at low ionic strength in the presence of a chelating agent (Eskildsen 1975 a). The precipitate formed was dissolved in PBS, $\mathrm{pH} 7.2$, to the original volume of serum. Trace of chelating agent was removed by dialysis against PBS, pH 7.2. After mixing of immune serum dilutions, antigen (2 units) and complement, each of which was used in amounts of $0.025 \mathrm{ml}$, the microplates were incubated at $4^{\circ} \mathrm{C}$ overnight. Then the haemolytic system was added in an amount of $0.025 \mathrm{ml}$, and after 
incubation at $37^{\circ} \mathrm{C}$ for $30 \mathrm{~min}$. the plates were left overnight at $4^{\circ} \mathrm{C}$, after which a final reading was made. The degree of haemolysis was scored by $+=100 \%$ haemolysis, $(+)=50-100 \%$ haemolysis, $(-)=0-50 \%$ haemolysis, $-=0 \%$ haemolysis. In the serum titrations (-) was taken as positive fixation.

\section{RESULTS \\ Complement fixation in block titration tests}

Fig. 1 presents the results of complement fixation in block titrations with the CSF virus as antigen. As immune serum was used a pool of two sera collected four weeks after inoculation with the Spielbach 66 strain of CSF virus. The serum was used both heated $\left(60^{\circ} \mathrm{C} / 30 \mathrm{~min}\right.$.) and treated with mercaptoethanol. With the heat-treated serum the specific complement fixation was partially masked by a haemolytic prozone as will be seen to the left in the figure. When the serum was treated with mercaptoethanol before use, the haemolytic prozone was eliminated completely (to the right in Fig. 1). Significant complement fixa-

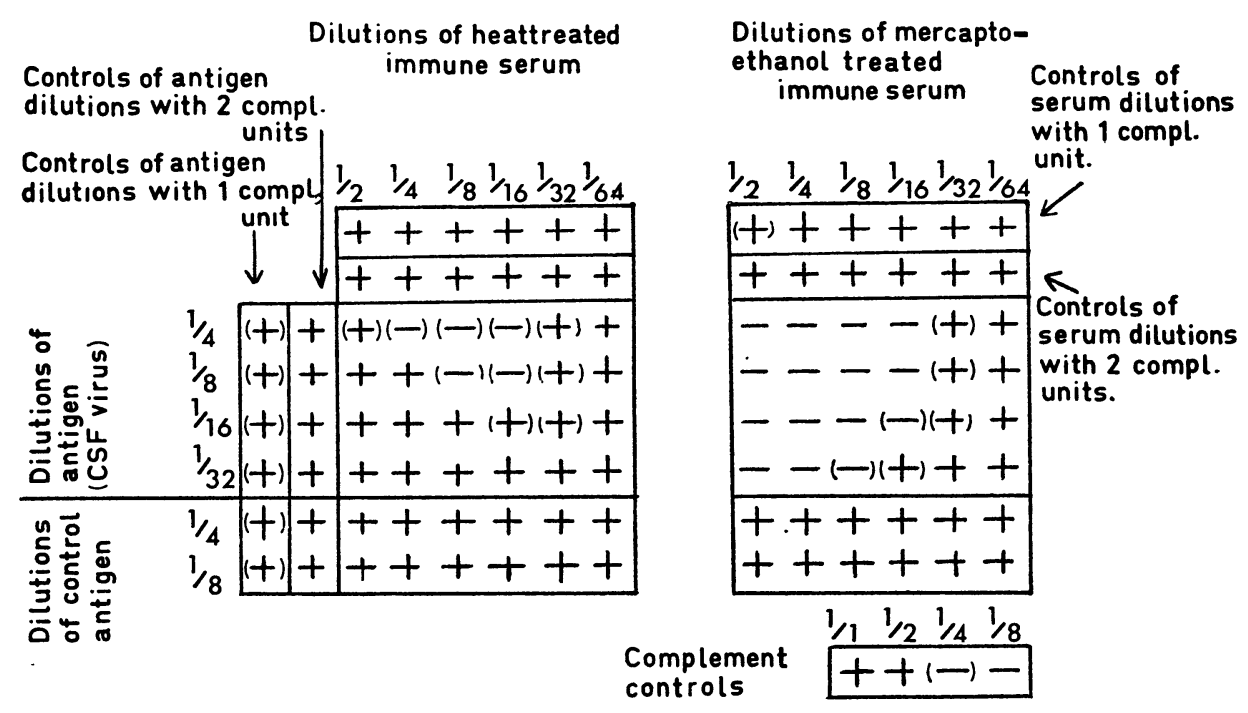

Figur e 1. Results of complement fixation in block titrations with heat-treated and mercaptoethanol-treated immune serum and CSF virus antigen. $+=100 \%$ haemolysis, $(+)=50-100 \%$ haemolysis, $(-)=0-50 \%$ haemolysis, $-=0 \%$ haemolysis. 


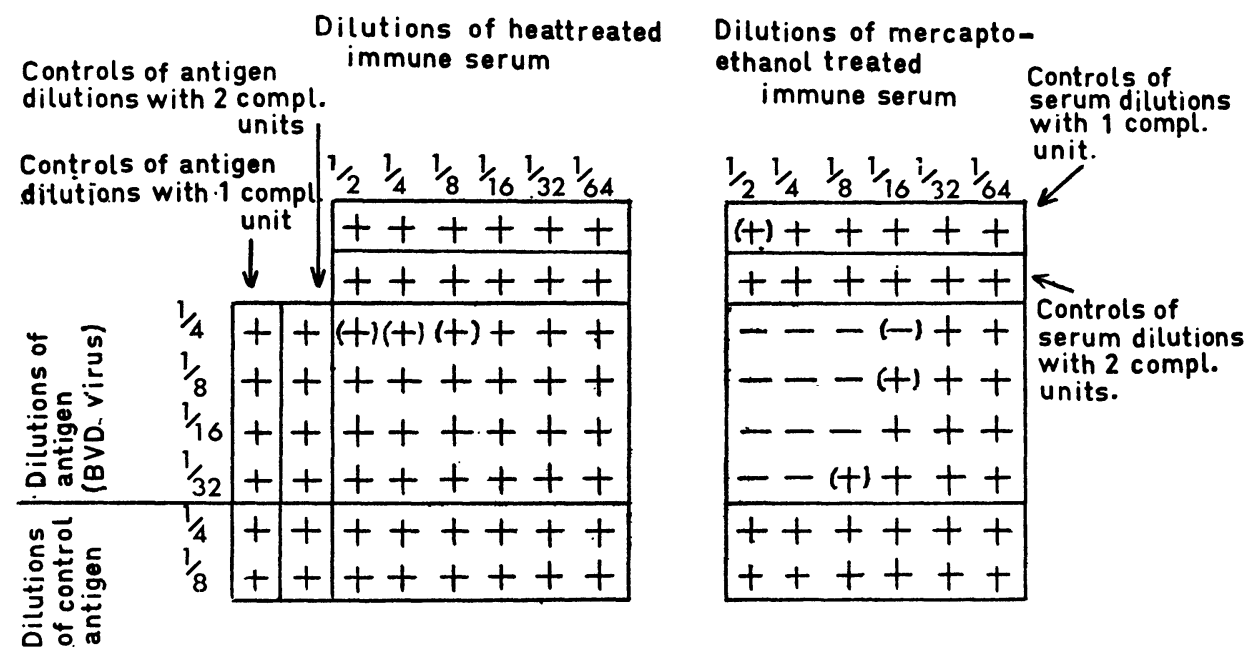

Figu re 2. Results of complement fixation in block titrations with the same heat-treated and mercaptoethanol-treated serum as shown in Fig. 1, and BVD virus antigen. For explanation of symbols see Fig. 1.

tion was obtained even with the lowest serum dilutions and the smallest amounts of antigen. There was no decrease in antibody titre owing to mercaptoethanol-treatment. Fig. 2 shows the results obtained when BVD virus was used as antigen. A haemolytic prozone was masking the specific complement fixation when heat-treated serum was used, whereas significant complement fixation was obtained with the mercaptoethanol-treated serum.

\section{Antibody response to the Hannover 62 strain}

Of the two pigs inoculated with the Hannover 62 strain of CSF virus the one died on the eighth day and virus was demonstrated in the tonsils by immunofluorescence. The only sign of infection of the other one was slightly elevated body temperature for a few days. The antibody level in post-infection sera was followed, and as will be seen in Fig. 3 there was a rapid increase in the titre of complement-fixing antibodies. Two weeks after inoculation the titre reached a maximum, which was followed by a decrease during the next weeks until a constant level during the following months. The neutralizing antibodies developed in a similar way, only a little more slowly. Both with the comple- 


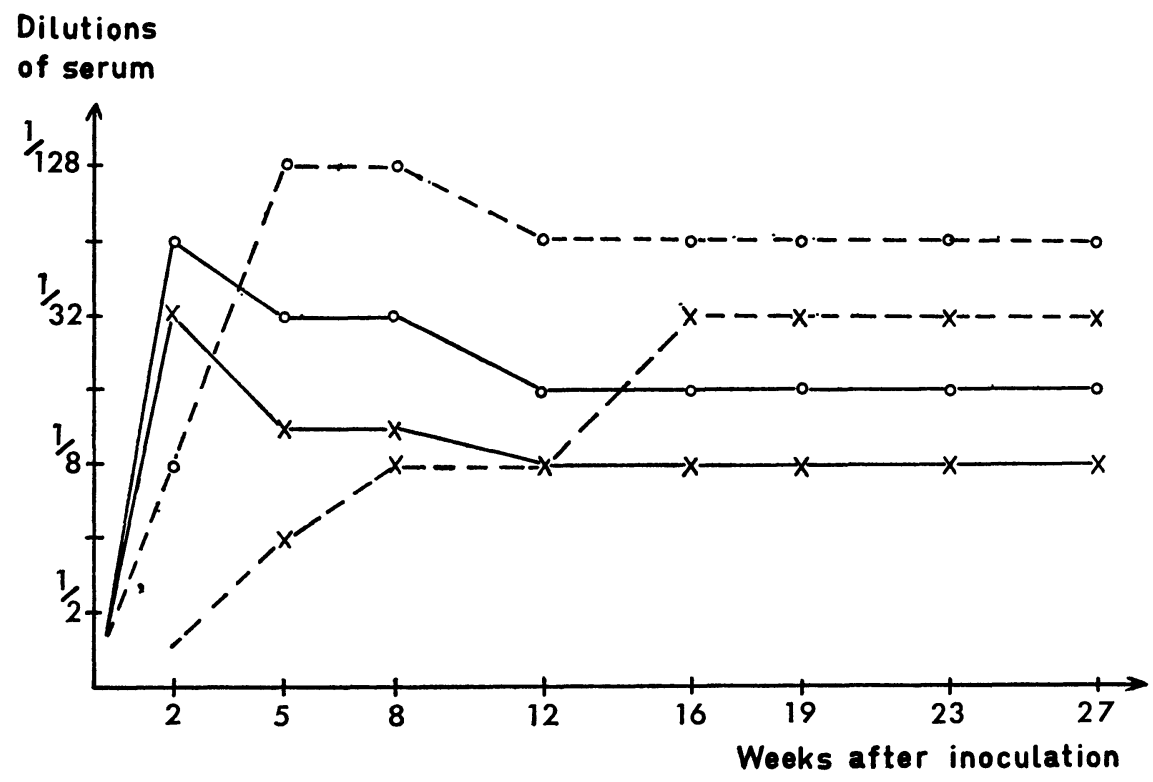

F i g u re 3. Antibody titres determined by complement fixation and immunofluorescence plaque neutralization test in post-infection sera from a pig inoculated once intravenously with the Hannover 62 strain of CSF virus.

$\mathrm{O}-\mathrm{O}$ titres obtained by complement fixation using CSF virus antigen.

$\mathrm{X}-\mathrm{X}$ titres obtained by complement fixation using BVD virus antigen.

O -.... O titres obtained by neutralization test using CSF virus.

$\mathrm{X}-\ldots . \mathrm{X}$ titres obtained by neutralization test using BVD virus.

ment fixation test and the immunofluorescence plaque neutralization test the antibody titres obtained using CSF virus were higher than those obtained with BVD virus.

Antibody response to the Spielbach 66 strain

Of the two pigs inoculated with the Spielbach 66 strain of CSF virus pig No. 1 had reduced appetite for two days and elevated body temperature on the fourth day after inoculation. In pig No. 2 no difference from normal behaviour was observed. In Fig. 4 are shown the antibody titres obtained with weekly sera collected within 13 weeks after inoculation of the two pigs. The complement-fixing antibodies developed rapidly and the titres were of the same magnitude whether CSF virus or BVD virus was used as antigen. Neutralizing antibodies were demonstrated a little later than the complement-fixing antibodies when 


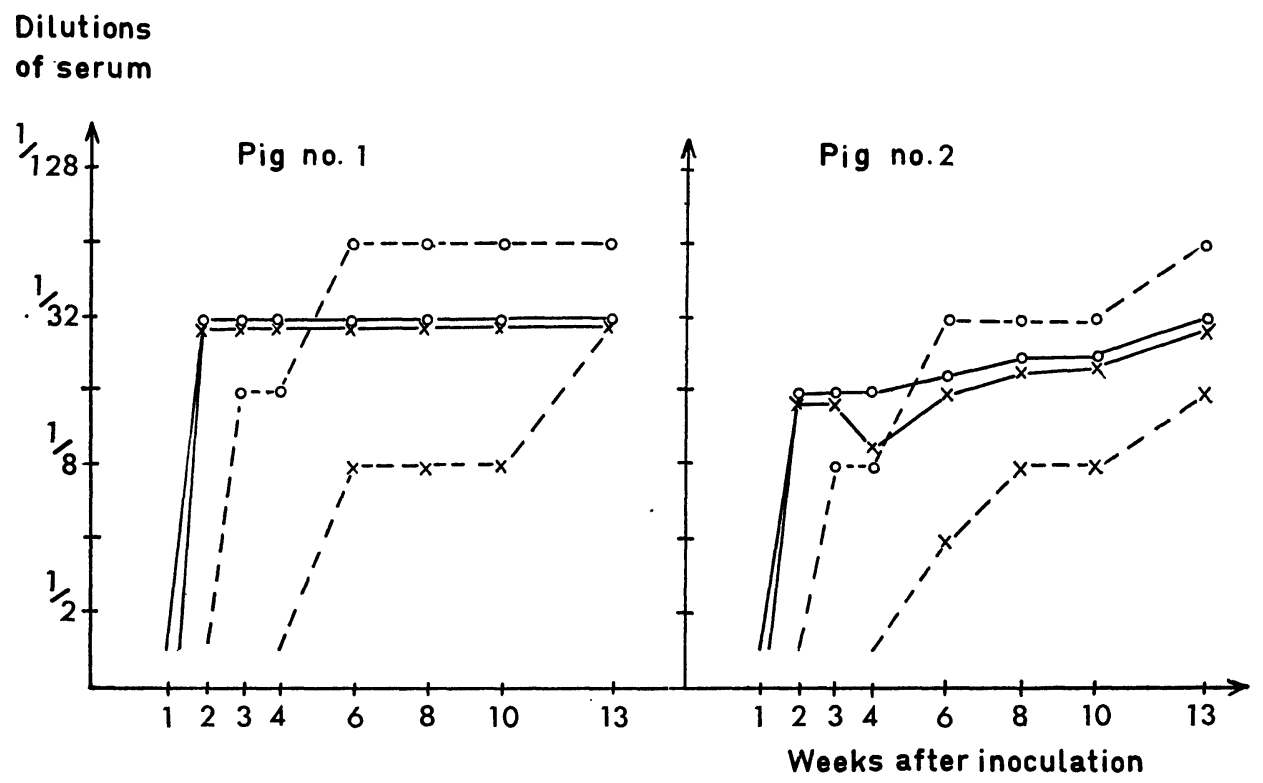

Figu r e 4. Antibody titres determined by complement fixation and immunofluorescence plaque neutralization test in post-infection sera from two pigs inoculated once with the Spielbach 66 strain of CSF virus.

$\mathrm{O}-\mathrm{O}$ titres obtained by complement fixation using CSF virus antigen.

$\mathrm{X}-\mathrm{X}$ titres obtained by complement fixation using BVD virus antigen.

O -.... O titres obtained by neutralization test using CSF virus.

$\mathrm{X}$-... $\mathrm{X}$ titres obtained by neutralization test using BVD virus.

CSF virus was used in the neutralization test. When BVD virus was used, neutralizing antibodies were not demonstrated until several weeks after inoculation, and the titres were low compared to those obtained with CSF virus. During the entire observation period of 13 weeks it was not possible to demonstrate complement-fixing or neutralizing antibodies in serum from the pig exposed to infection by contact with the two inoculated pigs.

\section{DISCUSSION}

The direct complement fixation test used in the present work was modified by the addition of a preparation of porcine C1q to the complement diluent since the presence of porcine C1q has been found to be of crucial importance for the specific fixation of guinea-pig complement by porcine pseudorabies antibody(IgG)-antigen complexes (Eskildsen 1975a). The haemo- 
lytic prozone problem, which is especially inconvenient in the case of swine sera with low antibody levels, was overcome by treatment of the sera with mercaptoethanol at $56^{\circ} \mathrm{C}$ before use (Eskildsen $1975 \mathrm{~b}$ ). This pretreatment has been shown to result in highly improved complement fixation reactions. If the sera were not treated with mercaptoethanol, only poor specific fixation was seen with the antigen preparations used.

In accordance with the serological relationship between CSF virus and BVD virus (Darbyshire 1962, Dinter 1963) complement-fixing and neutralizing antibodies could be demonstrated with both these viruses as antigens. Complement-fixing antibodies appeared relatively early with maximum titres about two weeks after inoculation. Neutralizing antibodies appeared somewhat later with maximum titres occurring about four or six weeks after inoculation. With BVD virus as antigen neutralizing antibodies were detected even later and with lower titres. With the sera from the pig inoculated with the Hannover 62 strain of CSF virus the antibody titres obtained using CSF virus were slightly higher than those obtained with BVD virus both in complement fixation and neutralization tests. With the sera from the pigs inoculated with the Spielbach 66 strain a similar difference in titres was not obtained by complement fixation, whereas there was a marked difference in the titres of neutralizing antibodies obtained with CSF virus and BVD virus, respectively. However, further studies are needed for clarifying the serological similarities and dissimilarities between these viruses.

The modified complement fixation test seems to be a sensitive method for detecting antibodies against CSF and BVD viruses. Being less laborious and time consuming than the immunofluorescence plaque neutralization test it may be useful as a routine diagnostic method.

\section{ACKNOWLEDGEMENTS}

The authors wish to thank Dr. G. Korn, Bundesforschungsanstalt für Viruskrankheiten der Tiere, Tübingen, for kindly providing the two strains of low virulent CSF virus.

\section{REFERENCES}

Borgen, H. C.: Mucosal Disease in Dänemark. II. Virologische und serologische Befunde in einen Bestand. (Mucosal disease in Denmark. II. Virological and serological findings in a herd). Nord. Vet.-Med. 1963, 15, 346-356. 
Boulanger, P., M. Appel, G. L. Bannister, G. M. Ruckerbauer, K. Mori $\&$ D. P. Gray: Hog Cholera III. Investigation of the complementfixation test for the detection of the virus in swine tissue. Canad. J. comp. Med. 1965, 29, 201-208.

Carbry, E. A., W. C. Stewart \& J. I. Kresse: Confirmation of hog cholera diagnosis by rapid serum-neutralization technique. J. Amer. vet. med. Ass. 1969, 155, 2201-2210.

Cowan, K. M.: Immunological studies on African swine fever virus. I. Elimination of the procomplementary activity of swine serum with formalin. J. Immunol. 1961, 86, 465-470.

Darbyshire, J. H.: Agar gel diffusion studies with a mucosal disease of cattle. A serological relationship between mucosal disease and swine fever. Res. Vet. Sci. 1962, 3, 125-128.

Dinter, $Z$.: Relationships between bovine virus diarrhoea virus and hog cholera virus. Zbl. Bakt., I. Abt. Orig. 1963, 188, 475-486.

Eskildsen, M.: Complement fixation with porcine serum antibodies. Enhancing effect of porcine C1q on complement fixation with IgG prepared from porcine pseudorabies immune serum. Acta path. microbiol. scand. Sect. C, 1975 a, 83, 315-324.

Eskildsen, M.: Demonstration of antibodies against pseudorabies virus in swine serum by a modified direct complement fixation test. Bull. Off. int. Epiz. 1975 b, XLIII ${ }^{\mathrm{e}}$ Ses. Gén., Rapp. no. 213.

Gutekunst, D. E. \& W. A. Malmquist: Complement-fixing and neutralizing antibody response to bovine viral diarrhea and hog cholera antigens. Canad. J. comp. Med. 1964, 28, 19-23.

Jakubik, J.: Die Komplementbindungsreaktion (Mikrometode) für den Antigen- und Antikörpernachweis bei der Schweinepest. (Complement fixation (micro-method) for the demonstration of hog cholera antigen and antibody). Dtsch. tierärztl. Wschr. 1969, $76,111-115$.

Korn, G., K. Schjerning-Thiesen \& H. Liebke: La mise en évidence d'antigenes et d'anticorps (immunofluorescence, réaction de fixation du complement, test de neutralisation et test au gel d'agar) dans un foyer de peste porcine classique ayant débuté par la mort de porcelets. (Determination of antigen and antibody employing different methods (immunofluorescence, complement fixation, the serum neutralization test and the agar gel test) at an outbreak of swine fever starting with death among new-born and elder piglets). Bull. Off. int. Epiz. 1969, XXXVII Ses. Gén., Rapp. no. 1235.

Mengeling, W. L.: A fluorescent microplaque assay for hog cholera virus. Arch. ges. Virusforsch. 1968, 23, 27-39.

Mengeling, W. L., D. E. Gutekunst, A. L. Fernelius \& E. C. Pirtle: Demonstration of an antigenic relationship between hog cholera and bovine viral diarrhoea by immunofluorescence. Canad. J. comp. Med. 1963 a, 27, 162-164.

Mengeling, W. L., E. C. Pirtle \& J. P. Torrey: Identification of hog cholera by immunofluorescence. Canad. J. comp. Med. 1963 b, $27,249-252$. 
Meyling, A. \& K. Schjerning-Thiesen: Study of the practicability of various diagnostic methods in the demonstration of swine fever virus of high and low virulence in organs of experimentally infected pigs. Acta vet. scand. 1968, 9, 50-64.

Overby, E.: Immunization against swine fever with a Danish bovine viral diarrhoea virus strain, UG 59. Nord. Vet.-Med. 1973, 25, $497-503$.

Schjerning-Thiesen, $K$. .: Studier over komplementbinding. En forbedret kvantitativ komplementbindingsteknik ved diagnosticering af aphtae epizooticae. (Studies of complement fixation. An improved quantitative technique of complement fixation in the diagnosis of aphtae epizooticae). A/S Carl Fr. Mortensen, Kфbenhavn 1964.

\section{SAMMENDRAG}

Serologisk diagnose af klassisk svinepest.

Antistofindholdet $i$ serum fra grise podet én gang med lavvirulente stammer af klassisk svinepestvirus blev målt ved komplementbinding og immunofluorescens med svinepestvirus (ALD stammen) og bovin virusdiarrhoea-virus (UG 59 stammen) som testantigener. To grise blev podet med Hannover 62 virusstammen og 2 grise blev podet med Spielbach 66 stammen, mens 1 gris blev anvendt som kontrolog kontaktdyr. Komplementbindingstesten var modificeret ved tilsætning af en præparation af porcint C1q til complementet og ved mercaptoethanolbehandling af immunserum $f \varnothing r$ anvendelsen. Denne mercaptoethanolbehandling resulterede $i$ en fuldstændig elimination af en hæmolytisk prozone, som ofte ses med porcine immunsera.

I serum fra de podede dyr kunne komplementbindende antistoffer påvises tidligere end neutraliserende antistoffer. Få uger efter podningen var der overensstemmlse mellem tilstedeværelsen af komplementbindende og neutraliserende antistoffer.

I hele observationsperioden på 13 uger var det ikke muligt at påvise komplementbindende eller neutraliserende antistof $i$ serum fra den gris, som var udsat for smitte ved kontakt med de 2 dyr, der var podet med Spielbach 66 virusstammen.

(Received February 10, 1976).

Reprints may be requested from: M. Eskildsen, The State Veterinary Institute for Virus Research, Lindholm, DK-4771 Kalvehave, Denmark. 